Review Article レビュー論文ーシリーズ 109

Invited Peer-Reviewed Article 招待査読論文

\title{
Current Status and Issues of Research on the Internationalization of Restaurant Chains:
}

Comparison with Research on Retail Internationalization

外食国際化研究の現状と課題

一 小売国際化研究との比較から-

\author{
Sohee Lee ${ }^{* 1}$ \\ 関西学院大学大学院 商学研究科 博士後期課程 \\ 李 素熙
}

${ }^{* 1}$ Graduate School of Business Administration of Kwansei Gakuin University, evn86296@kwansei.ac.jp

\begin{abstract}
While it is not an overstatement to say that the "Internationalization of restaurant chains" had been led by American restaurant chains over many years, it has entered a new phase in the 21st century, as the internationalization of Asian restaurant chains has expanded, being led by Japanese restaurant chains. To date, however, the phenomenon of this internationalization has been discussed only within the scopes of globalization and the spread of food culture, and only extremely limited discussions premised on corporate behaviors have been reported. Moreover, such research has mostly focused on grasping the current status of particular restaurant companies. These investigations used a diverse range of perspective in assessing the current status, with most of them providing only superficial analyses. Therefore, it is extremely difficult to review the studies accumulated in this field so far. In this study, we present four subjects for future investigations of these issues, referring to the perspectives employed in the research on the internationalization of retail, which is similar to the behavior of the internationalization of restaurant chains in many aspects.
\end{abstract}

Keyword : Basic characteristics, Local partner, Withdrawal behavior, Supply chain

要約 : 外食国際化は, 長らくアメリカの外食チェーンが牽引してきたと言っても過言でないが, 21 世紀に入ると, 日本の外食 企業を筆頭にアジア諸国の外食企業の国際化が進展し，外食国際化は新たな局面を迎えるようになった。しかしながら，外食国 際化現象は, グローバライゼーションを巡る議論や食文化の伝播を巡る議論の中で取り上げられる程度であり, 企業行動を前提 とした論考は非常に限られたものしか存在してこなかった。また, その限られた研究もほとんどが特定の外食企業の現状把握が 中心であり，それらの現状を捉える視角も非常に多様で，内容的には浅い分析にとどまるものが多く見られるのが実状である。 それゆえ，この領域の研究蓄積を整理することは非常に難しいのが実態である。そこで，本稿では，外食国際化行動と類似する 部分が多い小売国際化研究の研究視角を参照しながら, 外食国際化研究の現状を整理・理解した上で, 今後の研究課題を四点提 示した。

キーワード：主体特性, 現地パートナー, 撤退行動, サプライチェーン

Information : Received 24 June 2018; Accepted 26 July 2018

\section{I. はじめに}

近年, 日本の外食企業の海外進出が急増している。大 手の外食チェーンの海外店舗数を見ると, 吉野家の 775 店舗を筆頭に, 味千ラーメンが 703 店舗, サイゼリヤが
367 店舗, モスバーガーが 354 店舗と, かなりの数に達 している（店舗数は 2018 年 1 月時点）。海外に 100 店舗 以上を展開する日本の外食企業はすでに 14 社を数える に至っているのである。他方, 周辺のアジア諸国の外食 企業も積極的に海外進出を進めている。海外に 100 店舗 以上の規模で展開している企業だけを見ても, 韓国に 11 
Review Article レビュー論文ーシリーズ 109

企業, 台湾に 7 企業, 香港とシンガポールに 2 企業, フィリピンに 1 企業, 存在している（Lee, 2018）。外食 企業の海外進出といえば, 長らくアメリカの外食企業の 話であったが, 今や新しい時代が到来してきているとい えるのである。

とはいえ，このような外食企業の海外進出，ここでは 外食国際化と呼ぶが, それに関する研究は決して多いと はいえない。後にも見るように，1990 年代以降，英語圏 および日本において外食国際化現象は, グローバライゼー ションを巡る議論や食文化の伝播を巡る議論の中で取り 上げられる（触れられる）程度であり, 企業の海外進出 行動や海外戦略の視点から分析を行った研究は限られた ものしか存在してこなかった。とはいえ，その限られた 研究もほとんどが特定の外食企業の現状把握が中心であ り，それらの現状を捉える視点も非常に多様で, 内容的 には浅い分析にとどまるものが多く見られるのが実状で ある。それゆえ, この領域の研究蓄積を整理することは 非常に難しいのが実態である。

ところで，外食業は店舗を介して消費者と直接対峙す るという点で小売業と共通する特性を持っている1)。し たがって，その国際化においても，店舗を介した国際化 という点において小売業の国際化と類似するところが多 いといえる。「小売国際化」の研究分野は, これまでに蓄 積されてきた先行研究が多く存在し, その研究視角も明 確であるため, 小売国際化の研究視角が, 今後の外食企 業国際化研究にも応用できるところは少なくないと考え られる。特に, 1990 年代の初期の小売国際化研究は, 黎 明期に当たる外食国際化研究にとって参考になるものが 多いと考えられる。

そこで, 英語圈と日本において議論されてきた外食国 際化研究を概観するにあたり，本稿では「小売国際化」 の研究視角を参考に外食国際化研究を捉え直し, 外食国 際化研究の現状を把握・理解した上で, 今後の研究課題 を明らかにしたい。

\section{II. 外食国際化研究の始まり（初期の研究）}

外食企業の国際化という現象が本格的に研究対象とな
り議論され始めたのは, 1990 年代からとみてよい。しか しながら, それらの研究は, 国際文化論の領域における アメリカによる文化帝国主義への批判（60 年代～90 年 代）や，その批判への再批判（90 年代以降）など, マク ドナルドを対象としたグローバリゼーションの現象をめ ぐる議論であった。

それらの議論は, アメリカ文化が世界を席巻すること に対して危機を覚えた人たちが，マクドナルドのグロー バル化という現象を通じて, アメリカの文化的, 経済的 グローバル化に警鐘を鳴らすものだった。それに対して は, 自国文化の誇りを大切にするヨーロッパ人からの批 判はもちろんのこと,アメリカ国内からの批判もみられた。 その典型が, メリーランド大学教授であった社会学者 の Ritzer（1993）による批判である。Ritzerは, マクド ナルドの経営理念とそれを象徴する効率化・画一化が現 代社会のあらゆる場所に浸透していることを指摘し，そ れをマクドナルド化（McDonaldization）と名付けた ${ }^{2)}$ 。 これをきっかけに, 多くの研究者がマクドナルドをアメ リカ文化帝国主義のシンボル，あるいは画一化及び効率 化の象徵として批判するようになった（Alfino, Caputo \& Wynyard, 1998; Bové, Ariès \& Terras, 2000a; Bové, Dufour \& Luneau, 2000b; Clammer, 2001; Hyes \& Wynyard, 2002; Schlosser, 2001; Stillman, 2003)。

一方, フランスでは, 酪農家であると同時にアルテル モンディアリスム（Alter-globalization）の代表的運動家 であるボヴェが率いる一団が, 1999 年にマクドナルドの 店舗を解体する事件・デモを起こすなど, マクドナルド を「文化破壊の象徴」として敵視する風潮が強かった ${ }^{3)}$ 。 その事件の背景には, 第 2 次世界大戦後にフランスで も推し進められた農業の近代化・工業化により, ホルモ ン肥育牛や GMO（遺伝子組換え作物）など食への安全 性を摇るがす問題が起こり, フランス固有の食文化がグ ローバル外食企業によって侵食されかねないとの不安が あったことがうかがえる4)。

要するに, マクドナルドへの批判は, 標準化, 同一化, 産業化を象徵するアメリカナイゼーション (Americanization) への批判だけでなく, 食の安全やグ ローバリゼーションといった新たな敵に対する示威表現 であった（Sukapdjo, 2013）。つまり，マクドナルド化さ 
れたフード・インダストリーが，次第にグローバリゼー ションの批判の標的 (象徴) として用いられるようになっ たのである（Ashley, Hollows, \& Jones, 2004）。

一方で，マクドナルドへの観念論的批判に対する反論 も出現した（Fantasia, 1995; Illouz \& John, 2003; Keillor \& Fields, 1996; Ram, 2004; Smart, 1999; Traphagan \& Brown, 2002; Watson, 1997)。

その代表的な論者である Watson（1997）は, リッッァ らが言うマクドナルド化（McDonaldization）は，食を通 して世界中でアメリカ文化を一方的に植えつけるような 形で進行するのではなく，ローカリゼーション，すなわ ち現地化も同時に引き起こし，各地域の文化と融合しな がら世界各地で様々な形で展開されるものであると指摘 した。

また， Smart (1999) も，マクドナルド化 (McDonaldization) は，マックスウェーバーが提唱した 「合理化プロセスの拡張」として捉えるべきであると主張 した。彼は，消費者は，マクドナルドの広告や約束され た楽しみ，経済性に惹かれているのであって，合理化シ ステムに取り込まれているわけではないとした。

さらに, フランスのマクドナルドの従業員や顧客を対 象にしたインタビュー調査に基づき，ファースト・フー ド産業の詳細な研究を行った Fantasia（1995）も，国境 を超えた文化的影響は有害なもの（味の同一化や標準化, スピディーさは, フランス食習慣にとっての脅威である とする視角）であるとの主張には無理があるとし，その ような捉え方は, ファースト・フードのプロセスが社会 に及ぼした斬新性・革新性を見逃してしまうと指摘した5)。 それに加えて, Traphagan and Brown（2002）も，日本 におけるマクドナルドの大きな成功をグローバリゼーショ ンの指標として使われるべきではないと指摘した。マク ドナルドをはじめとする一部のファースト・フードチェー ンが日本市場において繁盛している理由は, マクドナル ドの店舗が西洋的あるいはグローバルであるからではな く，日本人の生活や文化に共感を呼ぶようなマクドナル ドのやり方の巧みさにあるとした ${ }^{6)}$ 。

Traphagan らは，国際的貿易や関係の対立が激しくな るにつれ，特定の多国籍企業は，政治的・経済的・文化 的へゲモニーもしくは国のイメージの都合の良いシンボ
ルとして用いられ，あるときは乱用・悪用されているこ とを指摘し， Ritzer や Schlosser, Clammer らによりマク ドナルドがターゲットになりやすかった理由として，マ クドナルドのゴールデンアーチが目立つことや，マクド ナルドが世界中に広がっていることを挙げている (pp. 132-133)。

このように, 社会学や文化人類学の領域における研究 は, グローバリゼーション, アメリカナイゼーション（効 率化・画一化）への反発, 懐疑論として, マクドナルド を都合の良いターゲットと利用してきたが， 21 世紀に入 ると，製造業を中心とした他産業での国際化の進展や， マクドナルドが海外市場で行われてきた現地適応化戦略 への注目が高まり（現地市場での苦戦や適応化の難しさ が顕著するにつれ)，多国籍企業およびマクドナルドに対 する観念論的批判は沈静化し，人々は次第に企業戦略と してのグローカリゼーション（Glocalization）に注目する ようになる 7 )。

では，日本ではどのような研究が行われてきたのであ ろうか。日本のアカデミックな文献の中で, 海外進出を 行った日系の外食企業を取り上げたものは，日本食文化 の海外移転を研究した Ishige, Koyama, Yamaguchi, and Ekuan（1985）の研究が最初であるとされる（Kawabata, 2016)。ただ, Ishige らの研究は, アメリカにおける日本 食の普及および受容の問題を文化人類学の視点から捉え たものであり，その研究対象も主に現地の個人経営の日 本食レストランであった。この傾向は, 2000 年代以降も 見られ，上海，シンガポール，ロンドンなどの世界各国・ 地域における日本食および日本食レストランの現状や普 及, 変容を, 食文化論的視点から捉える研究が進められ てきた（例えば, Arakawa, 2000; Iwama, 2013; Kawai, 2006; Ng \& Goda, 2001; Osawa, 2017 など)。

以上のように, 英語圈および日本における初期の外食 企業の国際化現象を取り上げた研究を概観してみると, 初期の研究は, 人文・社会学系の研究分野において, グ ローバライゼーションを巡る議論または食文化の伝播を 巡る議論の中で外食企業を取り上げたものがほとんどで, マーケティングの視点から外食企業の国際化行動を正面 から検討した研究はなかった。 


\section{2000 年以降の外食国際化研究}

しかしながら, 2000 年代に入ると, 日系の外食企業が 海外市場で成果を出すようになる。そのような現象に初 めて目をつけ, 外食企業の海外進出動向の整理を試み, 食文化の移転に果たす外食企業の役割の一端を明らかに したのが Kawabata（2002）である。そこでは，移転元の 食文化と移転先の消費者との間には外食企業のマネジメ ント戦略が介しており, その戦略の成功・失敗が, 食の 異文化間移転に少なから始影響を与えるとされた。つま り，これまでは食文化論の中だけで議論されてきた食の 越境・文化間移転の問題を, 企業戦略との関係から検討 したものである。

とはいえ，その後も，外食企業の国際化を外食企業の 戦略的視点から分析した研究は増えてはいない。その成 果は非常に限定的であり，日系外食企業の海外進出が急 増した 2010 年頃から，ようやく増えつつある程度である。

このように外食企業の国際化行動として分析した研究 は, 絶対量こそ少ないが, 非常に幅広い角度から行われ てきたため，それらを整理することは至難の業である。 それゆえ, 本稿では, 英語圈と日本に打ける研究が外食 企業の国際化現象の「何に」関心を示してきたのか，と いう視点から整理してみたい。

その際には，冒頭でも述べたように，外食国際化と共 通点が多く, 先行的に多くの研究が蓄積されてきた「小 売国際化」研究に扔ける研究視角を参考にしつつ, 整理・ 理解したい8)。なお，サーベイにあたっては，以下の二 点が考慮されていることを確認しておきたい。

第一に，外食産業（主にファースト・フード産業）を 対象とした文献は, サービス・マーケティングやブラン ディング領域を中心に膨大な数に上るが，そのほとんど は消費者行動に焦点が当てられたものである。しかし， 本稿では「企業行動」を前提とした論考を対象としてい るため，消費者行動を前提とする論考は対象外とした。

第二に，本章では，多店舗チェーン展開を行う外食企 業を対象とするため，個人経営の外食企業を対象とした 論考は対象外とする。

さて, 1990 年代までの小売国際化研究における研究視
角は以下に示すように 5 つあるとされる（Kawabata, 2000)。すなわち, (1)国際化の実態・進展状況への関心, (2) 進出動機・進出理由 - 意思決定過程への関心, (3)背後 にある戦略への関心, (4)国際化の障壁への関心, 5)進出 先市場に与えた影響への関心である。1990 年代までの小 売国際化研究は，いわば初期段階のものといえるが 2000 年代以降の外食国際化研究も同様の段階にあると考元ら れるため, まずはこの $5 つ の$ 視覚に従って外食国際化の 研究を整理してみたい。

\section{1. 国際化の実態・進展状況への関心}

英語圈の小売国際化研究では, 欧米小売企業や米国小 売企業, 日本小売企業といったように特定の国の小売業 に焦点を絞って国際化行動の実態および動向を分析する 研究が見られるが，日本の外食国際化の実態を捉えよう とする研究に打いても, 日本の外食企業に焦点を当てて, その海外進出を取り上げたものがよく見うけられる。例 えば，Tsuruoka（2008）は中国市場における日系外食 チェーン (吉野家, $\mathrm{CoCo}$ 壱番屋, サイゼリヤ, 味千ラー メン, 麦の穗) の事業展開を紹介している。また, Zhang （2013）は, 日系外食企業（吉野家, 味千ラーメン, サ イゼリヤ）の中国市場に拈ける事業展開を分析しつつ, 日系外食企業の海外進出㧍よび中国進出の動向を捉えて いる。さらに, Kawabata（2016）は, 日本の外食企業の 海外進出の全容とその歴史を解明している。

一方, Lee（2015）やKim（2017）は, 日系外食企業 の韓国進出を例に取り上げつつ, 日系外食企業の韓国進 出の現況について紹介している。

要するに, これらの研究は, 2000 年代以降の日系外食 企業の海外進出の増加拉よびアジア市場に打ける事業拡 大という新しい国際化現象への関心の表れであると考元 られる。ただし，これらは小売国際化研究と同じく幾つ かの企業の進出事例を紹介する程度のものが多く, 尚か つ企業紹介レベルを越えるものではなく分析の深まりに 欠けるものとなっている。

\section{2. 進出動機・進出理由・意思決定過程への関心}

小売国際化研究では, なぜ国際化したのかという海外 進出動機や要因, あるいはその意思決定過程に焦点を当 
てた研究が存在するが, 外食国際化研究においても，そ れらに注目した研究が見うけられる。例えば，日本の外 食企業がアジア市場に進出する動機・理由として，日本 国内の外食産業の縮小傾向や少子高齢化・人口減少など の環境要因と, アジア市場の中間層の増加㧍よび所得水 準の向上や日本食への関心の高まりなどの要因がよく挙 げられている（例えば, Tsuruoka, 2008, 2015; Zhang, 2013 など）。一方，Beak and Xu（2013）は，海外進出をする 上で組織の重要な意思決定過程の一つである参入モード の選択の問題に注目している。また，Kawabata（2010） は, 組織ガバナンスの手法とレベルに関する意思決定過 程について分析している。

\section{3. 背後にある戦略への関心}

小売国際化研究では, Treadgold and Davies（1988）や Wong（1998）など参入モードや進出先の選択などの個別 企業の国際化行動を戦略的に理解しようとした研究が見 られた。

外食国際化研究においても多様な視角から国際化行動 を理解しようとする研究が見られる。例えば, サービス． マーケティング分野でしばしば用いられる7P，つまり製 品 (Product), 価格 (Price), 場所 (Place), プロモー ション (Promotion), 業務プロセス (Process), 物的証 拠 (Physical Evidence), 人 (People) に沿って, Vignali （2001）はマクドナルドを, Tsuruoka（2015）は日系の外 食企業を対象に分析している。

外食企業のグローカルの重要性については Nandini （2014）も指摘している。マクドナルドは，品質基準に 関しては世界中同一水準を維持しながらも，商品（メ ニューや味) 抢よび価格, サプライ・チェーンのインフ ラストラクチャーなどに関しては，インドの文化的，経 済・社会的要素に基づいて積極的に現地適応化したこと, つまり，グローカリゼーション (Glocalization) こそがマ クドナルドのインドでの成功要因であるとした。

さらに, Crawford, Humphries, and Geddy（2015）は, マクドナルドを標準化と適応化戦略を融合させた優れた 組織として取り上げ，サウジアラビア，フランス，英国， ギリシャ,ブラジル，インドネシア，インド，中国，日 本，ニュージーランドの 10 カ国で，メニュー，プロモー
ション, 商標，レストラン（ここでは，進出形態を指す）, サービスという 6 つの次元からマクドナルドのグローカ ル戦略を検討している。

もちろん，グローカル戦略は，マクドナルドだけでな く，他の産業および多国籍企業においても見られる戦略 である。Miller（2004）は，マクドナルド以外にも， $\mathrm{KFC}$ ，スターバックス，ハーゲンダッツ (Häagen-Dazs), パパ・ジョンス (papa john's), シュロツキーズ・デリ (Schlotzsky's Deli)，ミスタードーナツ（Mister Donut） といった多くの米国系ファースト・フード企業が中国市 場でどのような適応化戦略を立ててきたのかについて， その詳細を記述している。

\section{4. 国際化の障壁への関心}

小売国際化研究では, 小売業が海外進出を行うにあ たって, どのような障壁が存在するのかという問題も研 究者の関心を集めてきた。例えば，K. Davies.（1993b， 1994，1995）のように進出先の政府の政策や規制要素が 外資系小売業の国際化の障壁として作用するという研究 や, Dupuis and Prime（1996）や Shacklton（1996）のよ うな文化的障壁により生じる問題について触れているも のなどがある。

世界のグローバル化が進展しているにもかかわらず, 世界には，文化的背景が異なるニーズを持つ多様な消費 者が存在している。それゆえに, 異なる文化的脈絡に打 ける消費者行動の違いを見極めることの重要性が増して きている。外食国際化研究に打いても, ビジネスの国際 化の進展により，国が異なる企業同士間の戦略的連携も 増えてきており，組織文化が国際化の障壁となる場面も みられるようになった。例えば, Lee, Madanoglu, and Ko （2013）は，スターバックスの韓国事業の合弁相手であ るスターバックス・コリア（シンセゲ・グループ）で行っ たインタビュー調査に基づき, 韓国事業が成功した要因 にはスターバックス本部と韓国のシンセゲ・グループの 使命や中核的価值が非常に似ていたことがあったとして いる。

また, Hadjimarcou and Barnes（1998）は, 米国のハン バーガー・チェーンであるシルバー・ストリーク（Silver Streak）がメキシコ進出を成功した要因の一つとして, 
Review Article レビュー論文ーシリーズ 109

現地パートナーが果たした役割を強調している。さらに， Andrade, Amorim, Pires, and Hemais（2013）が, ブラジ ル国内で 263 店舗を展開した外食企業のスポレート (Spoleto）の海外進出（スペインとメキシコ）の失敗事 例を紹介しつつ, その失敗要因の一つとして現地パート ナーとのパートナーシップの構築問題やガバナンスの問 題をコントロールすることの重要性を強調している。日 本における研究でも, Kawabata（2008a）が, 味千ラー メンが中国市場で成功を収めた理由の一つとして, 中国 側のパートナーとの信頼関係・役割を強調している。

すなわち, このことは, 現地パートナーの選択あるい は良好なパートナーシップの構築・維持の失敗が, 障壁 として作用しうることを示している。

さらに, Ryu, Jang, and Cho（2014）は, 中国の自治体 による外資系の外食企業に対する巧妙な政策（低い家貨 と税金優遇上のメリットを与えて市場参入ハードルを引 き下げた上で，進出後に毎年家賃を $10 \%$ ずつ引き上げて いくなど）や，高い転職率，古い製造設備によるコスト 増加（韓国に比べ電気代が 2 ～倍になるなど）などの 中国市場特有の厳しいビジネス環境を指摘している。そ の一方, Sato（2007）は中国政府の 2000 年以降の規制緩 和やフランチャイズの法整備により，本格的に外資企業 へ市場を開放し, 中国外食市場の成長が可能になったと している。このことは, 進出先市場の規制や政策的要因, インフラ設備要因, 労働環境要因などが障壁として作用 しうることを示している。

これらの障壁の他にも, 食材調達・加工・保管, 店舗 確保・開発, 人材確保・育成の三つの課題（障壁）を乗 り越える手法を, オペレーション・システムの視点から 理論的に整理した Kawabata（2013a, 2016）やそれらの課 題に注目した研究も見うけられる（例えば，Kuchino \& Oshima, 2016; Fujiwara, 2017)。

\section{5. 進出先市場に与えた影響への関心}

小売業国際化研究では, 小売業が海外市場に進出する ことにより, 現地小売業に与えた影響や地元メーカーと の紛争, 小売技術・ノウハウの国際移転研究などの問題 に触れた研究があった。

海外進出を行った外食企業も進出先市場に与える影響
は多岐にわたる。例えば，Lan and Khan（1995）は，香 港のファースト・フード産業の発展史を明らかにしてい る。そこには, マクドナルドや $\mathrm{KFC}$, ハーディーズ (Hardee’s)，ジャック・イン・ザ・ボックス（Jack in the box）などのアメリカのファースト・フード企業の香港進 出が, 品質やサービス, 清潔, 価值提供, 大量生産, マー ケティング戦略などの面において，地元のファースト・ フード産業を発展させたことが述べられている。また， Maumbe（2012）は, マクドナルドや KFC などの多国籍 企業が南アフリカに進出することは, 南アフリカの雇用 創出や収入創出にも寄与するところがあるとしている。

また, Sato（2007）や Beak, Chien, and Chuang (2013) は, 従来, 製造業や小売国際化研究において行われてき た「マーケティング技術移転」や，「小売企業の現地化プ ロセス」を外食企業に当てはめて考察している。

\section{6. その他}

外食国際化研究におけるその他の研究としては, 外食 企業の業種（主要メニュー）特性と国際化の難易度との 関係に着目した研究（例えば, Kawabata \& Chin, 2014; Lee, 2018）を挙げることができる。

本章では，英語圈および日本を中心としたマーケティ ング領域における外食企業の国際化行動に関する研究を 手短にサーベイし, 90 年代までの小売国際化研究の視覚 と照らし合わせながら, 外食国際化研究ではどのような 問題に関心を持たれてきたのかについて整理をしてみた。

表はそれをまとめたものである。もちろん, 外食国際 化研究には, 小売国際化研究には無かった特徵もある。

外食企業の国際化研究は, 大きく, アジア系の外食企 業の国際化を対象とした研究と, 米国の外食企業の国際 化を対象とした研究と分けて考える必要がある。アジア 系の外食企業の国際化行動は 2010 年以降に本格的に動 き出した比較的新しい国際化現象である。それゆえ, 研 究視点の幅はまだ小さく, 文献の数も非常に限られてい るのが実状である。内容的にも, ほとんどの研究の関心 は, 実態や進展状況の把握をすることに置かれており， 各外食企業のアジア市場における事例を紹介する程度に とどまっている。

一方, 米国のファースト・フード企業の国際化行動は, 


\begin{tabular}{|c|c|c|}
\hline 研究視角 & 小売国際化研究 & 外食国際化研究 \\
\hline $\begin{array}{l}\text { (1)国際化の実態· } \\
\text { 進展状況への関心 }\end{array}$ & $\begin{array}{c}\text { Burt (1991, 1993) } \\
\text { R. Davies (1992) } \\
\text { J. Davies and Jones (1993) } \\
\text { K. Davies and Fergusson (1995) } \\
\text { Robinson and Clarke-Hill (1995) } \\
\text { Mayer and Alexander (1996) } \\
\text { Haward (2000) }\end{array}$ & $\begin{array}{c}\text { Kawabata }(2002,2008 \mathrm{a}, 2008 \mathrm{~b}, 2016) \\
\text { Tsuruoka }(2008,2015) \\
\text { Zhang }(2013) \\
\text { Mogi }(2013) \\
\text { Lee }(2015) \\
\text { Kuchino and Oshima }(2016) \\
\text { Kim }(2017)\end{array}$ \\
\hline $\begin{array}{l}\text { (2)進出動機・進出理由・ } \\
\text { 意思決定過程への関心 }\end{array}$ & $\begin{array}{c}\text { Dawson }(1993) \\
\text { Alexander }(1997) \\
\text { Treadgold }(1988,1991) \\
\text { Williams }(1992 \mathrm{a}, 1992 \mathrm{~b}, 1994)\end{array}$ & $\begin{array}{c}\text { Zhang }(2013) \\
\text { Tsuruoka }(2008,2015) \\
\text { Kawabata }(2010) \\
\text { Beak and } \mathrm{Xu}(2013)\end{array}$ \\
\hline $\begin{array}{c}\text { (3)背後にある戦略への } \\
\text { 関心 }\end{array}$ & $\begin{array}{c}\text { Treadgold and Davies (1988) } \\
\text { Laulajainen (1991) } \\
\text { Burt (1993) } \\
\text { Wong (1998) } \\
\text { Tordjman (1995) } \\
\text { Wada (1987) } \\
\text { Muramatsu (1994) }\end{array}$ & $\begin{array}{c}\text { Vignali (2001) } \\
\text { Miller (2004) } \\
\text { Nandini (2014) } \\
\text { Crawford, Humphries and Geddy (2015) } \\
\text { Tsuruoka (2015) }\end{array}$ \\
\hline (4)国際化の障壁への関心 & $\begin{array}{c}\text { K. Davies (1993a, 1993b, 1994, 1995) } \\
\text { Kociecki (1998) } \\
\text { Dupuis and Prime (1996) } \\
\text { Shacklton (1996) } \\
\text { Quinn (1998) } \\
\text { Alekander (1997) }\end{array}$ & $\begin{array}{c}\text { Lee, Madanoglu and Ko (2013) } \\
\text { Ryu, Jang and Cho (2014) } \\
\text { Hadjimarcou and Barnes (1998) } \\
\text { Andrade, Amorim, Pires and Hemais (2013) } \\
\text { Sato (2007) } \\
\text { Mogi (2013) } \\
\text { Kuchino and Oshima (2016) } \\
\text { Kawabata (2008a, 2013a, 2013b, 2014, 2016) } \\
\text { Fujiwara (2017) }\end{array}$ \\
\hline $\begin{array}{c}\text { (5)進出先市場に与えた } \\
\text { 影響への関心 }\end{array}$ & $\begin{array}{l}\text { Malayang (1988) } \\
\text { K. Davies (1993b) } \\
\text { Goldman }(1981) \\
\text { Kacker }(1985,1988) \\
\text { Ho and Sin }(1987) \\
\text { Ho and Lau (1988) } \\
\text { Suzuki (1980) } \\
\text { Kato (1998) } \\
\text { Ko and Sato (1997) }\end{array}$ & $\begin{array}{c}\text { Lan and Khan (1995) } \\
\text { Maumbe (2012) } \\
\text { Sato (2007) } \\
\text { Beak, Chien and Chuang (2013) }\end{array}$ \\
\hline
\end{tabular}

出典：Kawabata（2000）の小売国際化研究の整理（pp. 268～276）を参考に筆者作成

20 世紀後半から始まっている。しかしながら，企業の 「国際化」に焦点を当てた研究の蓄積が少ないことや, ほ とんどの研究の関心が現地適応化問題に集まっており, 他の視角からのさらなる研究が必要となると考えられる。 また，米国の外食企業，特にファースト・フード企業は， 先進的なチェーン・オペレーションおよびマーケティン グ戦略を有していることから，新興国や発展途上国での 外食産業の近代化に与える影響に着目した研究も見られ
るのが特徵的である。

\section{IV. 今後の研究課題}

本稿では，これまでの外食国際化研究がどのような問 題に関心を向けてきたのかという観点から整理を試みた。 最後に, 外食国際化研究における問題点と今後の研究課 
題を四点提示しておきたい。

第一の課題は，主体特性と国際化行動の関連付けの弱 さである。小売国際化研究においても進出企業の業態や 規模といった特性と国際化行動との関係への関心が薄 かったが，外食国際化研究においても共通の課題を有し ている。すなわち，これまでは店舗の世界的広がりの大 きさから米国のファースト・フード企業が研究対象とな ることが多かったが, 外食企業といっても, ハンバーガー やピザなどのファースト・フードから, カフェー, ベー カリー，居酒屋など多種多様な業種および業態が国際化 の主体となっている。提供するメニューやサービスの仕 方（フル・サービスかセルフ・サービスか）はそれぞれ の業種および業態によって異なるにもかかわらず，これ ら外食企業の主体特性のバラエティを意識せず，国際化 行動が論じられてきた。その意味で, 外食国際化現象を 主体特性との関係の中で分析する必要があると考える。

第二の課題は, 現地パートナーの多様性と国際化行動 の関係に対してその関心が不足していることである。こ れまでの研究で指摘されてきたように，海外パートナー と国際フランチャイズ契約を結んで海外進出を行う際, パートナーの選定およびパートナーとの関係構築の難し さが重要な課題となってきた。

その海外パートナーには, 法人格を有する企業「法人 フランチャイジー (以下, 法人ジー)」が契約相手となる ケースも少なくないが, この法人ジーには, 多様な夕イ プが存在していることは注目に值する。すなわち，現地 の他業種企業（メーカーや小売業など）が副業で契約し ているケースや, 現地のフランチャイズ加盟店専業者 (Multi-unit-franchisee) が契約しているケース, 現地の異 業態のフランチャイズ本部が契約しているケースなどで ある。

実際に，日本に進出してきた海外の外食フランチャイ ズ企業の契約相手もまたこの法人ジーがほとんどを占め ており，たとえば小売業，電鉄会社，日本の外食本部な どそれも多様性を有している。しかしながら，これまで の研究では, 契約相手を,「海外パートナー」と一括して 捉えてきたため, 法人ジーの多様な特性が議論されてこ なかった。したがって, 外食国際化の進展要因や阻害要 因などを検討する際も，法人ジーの特性から捉える必要
があるといえよう。

第三の課題は，撤退行動や閉店現象の研究不足である。 小売国際化においては, Kawabata（2000）や Toba（2006, 2008,2009）などが見られるが，外食国際研究ではまだ 手が付けられていない。しかしながら, 現実には海外市 場においてなかなか利益が出ずに苦戦するあるいは撤退 する企業も多数存在しており, 海外市場における事業展 開の課題は少なくないというのも事実である。そのため, 進出後, 1 号店が開店するところから始まり, その後に 増店や閉店を経て, 最終的に市場から撤退していくとい う一連の出店行動をトータルに捉え, その背後にあるメ カニズムを解明することも必要であるといえよう。

最後の課題は, サプライチェーンの構築に対する関心 の弱さである。外食企業は小売業の特性のみならず, 多 様な食材を調達し, 加工・調理するなどのサプライチェー ンの構築を必要とする製造業の特性を有している。 Tsuruoka（2008）も指摘するように, 事業規模や進出地 域が拡大すればするほど, 食材の安全性の確保・均一性 などが大きな課題となり, 食材の供給ルートの効率化と 品質の維持が求められるようになる。それゆえ, 店舗の 開発や確保, 人材確保および育成の要素のみならず, 食 材 (原料) サプライヤーなどの関連企業との関係および サプライチェーンの構築も店舗を拡張するにあたって欠 かせない要素である。したがって, 進出先市場において, 食材をどこから調達し, 加工・調理するかなどの問題も 解明する必要があると言える。

注

1）ただし, 食材を調達し, 加工・調理するという製造業と共 通する特性も有する。とくに, 多様な食材の調達網の構築 は, 製造業のサプライチェーン構築と同じと見なせる。す なわち, 外食企業の海外進出は, 進出先での店舗の開発と サプライチェーンの構築の 2 つの側面から捉える必要があ るといえる。

2） Ritzer（1993）は, マクドナルドから効率性（efficiency）, 計算可能性 (calculability), 予測可能性 (predictability), 制 御（control）という4つの要素を見出し，マクドナルドの 食事をする場所や作業をする場所が合率化かつ脱人間的な 環境に変わってきたことが, 現代社会のあらゆる場所に浸 透していることを指摘し, それをマクドナルド化 (McDonaldization) と名づけた。

3） 1999 年 8 月 12 日, ジョージ・リッツァと彼が務める農民 同盟が中心となり，南仏の小都市であるミヨーに建設中で 
あったマクドナルドの店舗を破壊する事件が起きる。この 事件の発端となったのが, 欧州が米国のホルモン肥育牛肉 の輸入を禁止したことへの報復として，米国がフランス産 のロックフォールチーズに対する制裁関税を課したことで あった。それへの抗議として，マクドナルドを多国籍企業 による文化破壊の象徴として見立て，それをターゲットと した事件であった。

4) Bové, Ariès, and Terras (2000)

5）彼は，変革を起こしうる効果の例として，マクドナルドの 成功を追随したフランス発のハンバーガー・チェーンが, 自らアメリカ的な響きをもつ店舗名を使って市場に進出し ていたことや(例えば, Frence-Quick, Magic Burger, B’Burger, Manhattan Burger, Katy's Burger, Love Burger, and Kiss Burger)，マクドナルド化（中央化された倉庫から供給さ れ，機械化されたキッチン，標準化されたレシピやプロセ スなど）を基盤とした伝統的なフランスのスナック（クロ ワッサン）を提供する他のファースト・フード企業の成功 例を挙げ,「クロワッサンとハンバーガーの交換が決して同 等の文化的交換や文化的に近似していることを意味してい るのではない」(p.234) と主張した。

6）例えば, 世帯ごとに $2 \sim 3$ 台以上持つ車社会の出現に応じ, バイパス沿いにドライブスルー型の店舗を出したことなど (p. 132)

7）マクドナルドをめぐる議論は，Beck（1997）が,「文化理 論を学んだアングロサクソン系の観察者たちは，このよう な，世界の『マクドナルド化』と呼びうるものに別れを告 げた」とし，「グローバル化が文化の画一性をもたらすもの ではないという点では, みな意見が一致している」(p.111) としたように，今世紀の初頭になる頃には終息を告げるよ うになった。

8）ここでの小売国際化研究は，主に百貨店，GMS，SM の国 際化を取り上げる初期の研究を対象となっており，2000 年 代以降の SPA (speciality store retailer of private label apparel）などの専門店の国際化に関する研究は対象となっ ていない。

\section{References}

Alexander, N. (1997). International Retailing. Blackwell, Oxford, $330 \mathrm{p}$.

Alfino, M., Caputo, S., \& Wynyard, R. (eds) (1998). McDonalization revisited: Critical essays on consumer culture. Praeger.

Andrade, O. V. M., Amorim, R. P. B., Pires, F. C., \& Hemais, M. W. (2013). Spoleto: Internationalizing a Brazilian franchise of Italian cuisine. Academia , 26(3), 415-431.

Arakawa, M. (2000). Shoku to keizai no gurobaruka. In Kawai, T. (Ed.), Hikakushokubunkaron: Bunkajinruigaku no shiten kara (pp. 120-140). Japan: Kenpakusha.（荒川正也（2000）。「食と 経済のグローバル化」河合利光（編）『比較食文化論：文化 人類学の視点から』健帛社, 120-140) (In Japanese)

Ashley, B., Hollows, J., \& Jones, S. (2004). Food and cultural studies (Studies in Consumption and Markets). Routledge.

Beak, J. Y., \& Xu, U. (2013). Akindosushiro no kaigaisinshutu to chitekiiten. Bulletin of Department of Management Information, Faculty of Management, Fukuyama Heisei
University, 9, 127-145.（白貞壬・徐ウンジ（2013）。「あきん どスシローの海外進出と知識移転」『福山平成大学経営学部 経営学科紀要』9, 127-145) (In Japanese)

Beak, J. Y., Chien, S. Y., \& Chuang, Y. (2013). Entering overseas of Taiwan's small businesses in the restaurant industry. East Asian Studies, 58, 53-64. (白貞壬 ·簡施儀・莊苑仙 (2013). 「台湾外食業界に抢ける中小企業の海外進出」『東アジア研 究』58, 53-64） (In Japanese)

Beck, U. (1997). Was ist Globalisierung?: Irrtumer des Globalismus -Antworten auf Globalisierung. Suhrkamp Verlag. (木前利 秋・中村健吾監（訳）（2005）。『グローバル化の社会学』国 文社)

Bové, J., Ariès, P., \& Terras, C. (2000a). la revolte d'un paysan, Edition Golias.（杉村昌昭（訳）(2002）、『ジョゼ・ボヴェ： あるフランス農民の反逆』柘植書房新社)

Bové, J., Dufour, F., \& Luneau, G. (2000b). Le monde n'est pas une marchandise: des paysans contre la malbouffe. La Découverte. (新谷淳一（訳）（2001）。地球は売り物じゃない』紀伊國 屋書店)

Burt, S. L. (1991). Trends in the internationalization of grocery retailing: The European Experience, the international review of retail. Distribution and Consumer Research, 1(4), 487-515.

Burt, S. L. (1993). Temporal trends in the internationalization of British retailing. The International Review of Retail, Distribution and Consumer Research, 3(4), 391-410.

Clammer, J. (2001). Japan and its others: Difference and the critique of modenity. Melbourne.

Crawford, A., Humphries, S. A., \& Geddy, M. M. (2015). Mcdonald's: A case study in glocalization. Journal of Global Business Issues, 9(1), 11-18.

Davies, K. (1993a). Trade barries in East and South East Asia: The implications for retailers, proceedings of 1st E. S. R. C. seminar series: Research themes in retailing, Manchester (Theme 1: International Issues in Retailing), 15th March.

Davies, K. (1993b). Retailing in Singapore: Coping with change? International Journal of Retail \& Distribution Management, 21(1), 10-20.

Davies, K. (1994). The implications of foreign investment in the retail sector: The example of Singapore. The Developing Economies, 22(3), 299-330.

Davies, K. (1995). The regulation of retail internationalisation: Examples from the Pacific Asia region. In McGoldrick, P. J., \& Davies, G. (eds.), International retailing: Trends and strategies. Pitman Publishing, 151-164.

Davies, K., \& Fergusson, F. (1995). The international activities of Japanese retailers. The Service Industries Journal, 15(4), 97117.

Davies, J. B., \& Jones, P. (1993). International activity of Japanese department stores. The Service Industries Journal, 13(1), 126132.

Davies, R. (1992). The internationalisation of retailing. In David, R. (ed.), Risks and opportunities in retailing in the 1990's. Newman Books, 65-84.

Dawson, J. A. (1993). The internationalization of retailing. In 
Bromley, R, D, F., \& Thomas, C. J. (eds.), Retail change: Contemporary issues. London: UCL Press, 15-40.

Dupuis, M., \& Prime, N. (1996). Business distance and global retailing. International Journal of Retail \& Distribution Management, 24(11), 30-39.

Fantasla, R. (1995). Fast food in France. Theory and Society, 24, 201-243.

Fujiwara, M. (2017). Ootoya: Tennaichouri no kaigaitenkai. In Itami, H., Takahashi, K., Nishino, K., Fujiwara, M., \& Kishimoto, T. Overseas experience of service innovation: Nihonkigyou no seikoujirei to sonoyouinbunseki (59-86). Japan: Toyo Keizai.（藤原雅俊（2017）。「大戸屋：店内調理の海外 展開」伊丹敬之・高橋克徳・西野和美 - 藤原雅俊 - 岸本太 一『サービスイノベーションの海外展開：日本企業の成功 事例とその要因分析』東洋経済新報社, 59-86) (In Japanese)

Goldman, A. (1981). Transfer of retailing technology into the less development countries: The Supermarket Case. Journal of Retailing, 57(2), 5-29.

Hadjimarcou, J., \& Barnes, J. W. (1998). Case study: Strategic alliances in international franchising - the entry of Silver Streak Restaurant Corporation into Mexico-. Journal of Consumer Marketing, 15(6), 598-607.

Haward, E. (2000). European Retailers' Approach to Asian Markets, Paper presented to 'Asian Pacific Retail Conference 2000', Hosei University, Tokyo Japan, 1-2th March.

Ho, S., \& Lau, H. (1988). Development of supermarket technology: The incomplete transfer phenomenon. International Marketing Review, 5(1), 20-30.

Ho, S., \& Sin, Y. (1987). International transfer of retailing technology: The successful case in convenience store in Hong Kong. International Journal of Retailing, 2(3), 36-48.

Hyes, D., \& Wynyard, R. (2002). The McDonaldization of higher education. Westport, CT: Bergin and Garvey.

Illouz, E., \& John, N. (2003). Global habitus, local stratification, and symbolic struggles over identity. American Behavioral Scientist, 47(2), 201-229.

Ishige, N., Koyama, S., Yamaguchi, M., \& Ekuan, S. (1985). Japanese restaurants in Los Angeles: Sonobunkajinruigakutekikenkyu. Japan: Domesu Publishers. (石毛直道・小山修三・山口昌伴・栄久庵祥二 (1985).『口 サンゼルスの日本料理店一その文化人類学的研究』ドメス) (In Japanese)

Iwama, K. (2013). Japanese food culture in Shanghai: A report of listening research on the menu localization. Chiba University of Commerce Review, 51(1), 1-54.（岩間一弘（2013）。「上海 の日本食文化一メニューの現地化に関するヒアリング調査 報告一」『千葉商大紀要』51(1), 1-54） (In Japanese)

Kacher, M. P. (1985). Transatlantic trends in retailing: Takeovers and flow of know-how. Quorum Books, 165.

Kacker, M. P. (1988). International flow of retailing know-how: Bridging the technology gap in distribution. Journal of Retailing, 64(1), 41-67.

Kato, T. (1998). Ryuutsuugaishi no kyousouryoku: Sono "iten" kanousei no mondai wo kangaeru. Japan Marketing Journal,
68, 4-15.（加藤司（1998）.「流通外資の競争力一その「移 転」可能性の問題を考える一」『マーケティング・ジャーナ ル』, 68, 4-15) (In Japanese)

Kato, T. (Ed.) (2006). Shokukara no ibunkarikai: Teemakenkyuu to jissen. Japan: Jichosha.（河合利光（編）（2006）.『食からの 異文化理解 : テーマ研究と実践』時潮社) (In Japanese)

Kawabata, M. (2000). The internalization of Japanese retailers: Locations and strategies. Japan: Shinhyoron Publishing. (川端

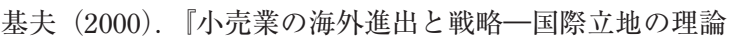
と実態一』新評論）(In Japanese)

Kawabata, M. (2002). Nikkeigaishokusangyo no kaigaishinshutu: Shokubunka no kokusaika no kadai. Kenkyukiyo, 15, 69-74. (川 端基夫（2002）。「日系外食産業の海外進出一食文化の国際 化の課題一」『研究紀要』15,69-74）(In Japanese)

Kawabata, M. (2008). Zoudai suru nihon no gaishokucheen no kaigaishinshutu. Ryuutsu to Shisutemu, 135, 72-78. (川端基夫 (2008a)。「増大する日本の外食チェーンの海外進出」『流通 とシステム』, 135, 72-78) (In Japanese)

Kawabata, M. (2008). Gaishokucheen no chuugokushijyoushinshutu: Ajisen raamen wa naze hiyaku dekitanoka. Ryuutsuujyoho, 466, 4-13. (川端基夫 (2008b).「外食チェー ンの中国市場進出：味千ラーメンはなぜ飛躍できたのか」 『流通情報』，466, 4-13）(In Japanese)

Kawabata, M. (2010). Nihonkigyou no kokusaifuranchaijingu: Shinkoushijyousenryaku toshiteno kanousei to kadai. Japan: Shinhyoron Publishing. (川端基夫（2010）。『日本企業の国 際フランチャイジング一新興市場戦略としての可能性と課 題一』新評論) (In Japanese)

Kawabata, M. (2013). Dynamics of globalization in food service sector: Japanese fast food chains in Asian markets. Journal of Marketing \& Distribution, 15(2), 3-23. (川端基夫（2013a). 「外食グローバル化のダイナミズム：日系外食チェーンのア ジア進出を例に」『流通研究』15(2), 3-23) (In Japanese)

Kawabata, M. (2013). Processes of building ingredient procurement systems abroad by Japanese ramen restaurant chains: Obstructive factors to cross-border standardization of taste. Journal of Business Administration, 60(4), 325-341.（川 端基夫 (2013b).「日系ラーメンチェーンによる海外での食 材調達システムの構築プロセス一国境を超えた味の標準化 に対する阻害要因一」『商学論究』60(4), 325-341) (In Japanese)

Kawabata, M. (2014). The role of supporting industries to overseas expansion of Japanese food service firms. Journal of Business Administration, 62(1), 41-59. (川端基夫（2014）。「日系外食 企業の海外進出に果たすサポーティング・インダストリー の役割」『商学論究』62(1), 41-59) (In Japanese)

Kawabata, M. (2016). Gaishokukokusaika no dainamizumu: Atarashii "ekkyou no katachi”. Japan: Shinhyoron Publishing. （川端基夫（2016）。『外食国際化のダイナミズム一新しい 「越境のかたち」一』新評論) (In Japanese)

Kawabata, M., \& Chin, S. (2014). Taiwankeigaishokucheen no kyuusokuna kokusaika to sonoyouin: Nikkeigaishokucheen eno shisa. Ryuutsuujyoho, 46(3), 41-49. (川端基夫 · 陳静樺 (2014).「台湾系外食チェーンの急速な国際化とその要因一 
日系外食チェーンへの示唆一」『流通情報』46(3), 41-49) (In Japanese)

Keillor, B. D., \& Fields, D. M. (1996). Perceptions of a foreign service offering in an overseas market: The case of fast food in Hong Kong. Journal of International Consumer Marketing, 9(1), 83-104.

Kim, H. J. (2017). The development of Japanese foodservice companies in Korea: The case analysis of CoCo ICHIBANYA Bulletin of Shizuoka Sangyo University, 19, 121-136.（金炣中 (2017).「日系外食企業の韓国進出戦略：CoCo 壱番屋の事 例を中心に」『静岡産業大学情報学部研究紀要』19, 121136) (In Japanese)

Ko, S., \& Sato, Y. (1997). Taiwan no daikibokourigyou to meekaa tono funsou: Karufuuru to sebunirebun no keesu wo chuushinni. Ryuutsuujyouhou, 338, 31-39.（黄士哲・佐藤善信 (1997)。「台湾の大規模小売業とメーカーとの紛争一カル フールとセブンイレブンのケースを中心に一」『流通情報』 338, 31-39) (In Japanese)

Kuchino, N., \& Oshima, K. (2015). Saizeriya's strategies and problems in Chinese food service market. St. Andrew's University Economic and Business Review, 56(3), 1-11.（口野 直隆・大島十二 (2015)。「サイゼリヤ」の中国戦略の現状 と課題」『桃山学院大学経済経営論集』56(3), 1-11) (In Japanese with English abstract)

Kuchino, N., \& Oshima, K. (2016). Overseas promotion by Japanese food service industry: A case study of Ootoya. St. Andrew's University Economic and Business Review, 58(2), 116.（口野直隆・大島十二 (2016)。「日系外食産業の海外進 出戦略 : 大戸屋の事例を中心に」『桃山学院大学経済経営論 集』58(2), 1-16) (In Japanese)

Kociecki, R. E. (1998). Barriers to entry in central European markets-Case study: Office Depot-. European Retail Digest, Issue 19, September, 54-56.

Lan, L., \& Khan, M. A. (1995). Hong Kong's fast-food industry: An overview. Cornell Hotel and Restaurant Administration Quarterly, 36(3), 34-41.

Laulajainen, R. (1991). Two retailers go global-The geographical dimension. The International Review of Retail, Distribution and Consumer Research , 1(5), 607-626.

Lee, K. H., Madanoglu, M., \& Ko, J. Y. (2013). Developing a competitive international service strategy: a case of international joint venture in the global service industry. Journal of Service Marketing, 27(3), 245-255.

Lee, M. H. (2015). Gaishokukigyou no kokusaimaakechingusenryaku nikansuru jireichousa. Nihon Fuudo Saabisugakkai Nenpo, 20, 50-63.（李美花（2015）。「外食企 業の国際マーケティング戦略に関する事例調査」『日本フー ドサービス学会年報』20,50-63）(In Japanese)

Lee, S. H. (2018). Relationship of the basic characteristics of restaurant chains with their internationalization behavior and resulting performance. Kwansei Gakuin Shogaku Kenkyu, 74, 29-62. (李素熙（2018）。「外食企業の主体特性と国際化行 動・成果との関係性」『関西学院商学研究』74, 29-62) (In Japanese)
Malayang, R. V. (1988). The distribution industry in Asian NIES and ASEAN countries and the effects of the entry of Japanese retailers. Management Japan, 21(2), 15-28.

Maumbe, B. (2012). The rise of South Africa's quick service restaurant industry. Journal of Agribusiness in Developing and Emerging Economies, 2(2), 147-166.

Miller, P. M. (2004). Quick service hits China. The China Business Review, 31(4), 18-28.

Mogi, S. (2013). The advancement of foodservice industry within Asia. Hospitality Management, 4(1), 59-74.（茂木信太郎 (2013)。「外食産業のアジア進出について」『ホスピタリ ティ・マネジメント』4(1), 59-74) (In Japanese)

Muramatsu, J. (1994). Growth strategy in retail corporation and internationalization. Journal of International Economics, 1, 4756. (村松潤一 (1994).「小売企業の成長戦略と国際化」『国 際経済論集 (常葉学園浜松大学)』創刊号, 47-56) (In Japanese)

Myers, H., \& Alexander, N. (1996). European food retailer's evaluation of global markets. International Journal of Retail \& Distribution Management, 24(6), 34-43.

Nandini, A. Satya. (2014). McDonald's success story in India. Journal of Contemporary Research in Management, 9(3), 21-31.

Ng, W., \& Goda, M. (2001). The popularization of Sushi in Singapore: Issues in globalization and localization. Japanese Journal of Southeast Asian Studies, 39(2), 258-274. （呉偉明 合田美穂 (2001).「シンガポールにおける寿司の受容 : 寿 司のグローバライゼーションとローカライゼーションをめ ぐって」『東南アジア研究』39(2), 258-274) (In Japanese with English abstract)

Osawa, Y. (2017). Eikoku rondon niokeru nihonshoku no gurookaraizeeshon to bijinesu. In M. Arata (Ed.), Bunka wo taberu bunka wo nomu: Gurookarukasuru sekai no shoku to bijinesu (pp. 215-230). Japan: Domesu Publishers.（大澤由実 (2017).「英国ロンドンに扔ける日本食のグローカライゼー ションとビジネス」(阿良田麻里子（編）『文化を食べる文 化を飲む一グローカル化する世界の食とビジネスー』ドメ ス, 215-230)）(In Japanese)

Quinn, B. (1998). The internationalization process of franchise system: An ethnographic study. Asia Pacific Journal of Marketing \& Logistic, 10(2), 68-84.

Ram, U. (2004). Glocommodification: How the global consumes the local-McDonald's in Israel. Current Sociology, 52(1), 11-31.

Ritzer, G. (1993). The McDonaldization of society: An investigation into the changing character of contemporary social life. Pine Forge Press.（正岡寞司（訳）（2001）、『マクドナルド化す る社会』早稲田大学出版部, 1996 年刊行の Revised Edition の訳）

Robinson, T. M., \& Clarke-Hill, C. M. (1995). International alliances in European retailing. In McGoldrick, P. J., \& Davies, G. (eds.), International retailing: Trends and strategies. Pitman Publishing, 133-150.

Ryu, S. M., Jang, W. J., \& Cho, H. J. (2014). China market entry strategy of Paris Baguette. Journal of Business Case Studies, 10(2), 155-164. 
Sato, K. (2007). Nihon no gaishokukigyou no chuugokushinshutu. Senshuukeieikenkyuunenpo, 32, 13-30. (佐藤康一郎 (2007). 「日本の外食企業の中国進出」『専修経営研究年報』32,1330) (In Japanese)

Schlosser, E. (2001). Fast food nation: The dark side of the allAmerican meal. New York: Houghton Mifflin.（榆井浩一（訳) (2008).『ファーストフードが世界を食いつくす』草思社) (In Japanese)

Shackleton, R. (1996). Retailer internationalization: A culturally constructed phenomenon. In Wrigley, N., \& Lowe, M. (eds.), Retailing, consumption and capital. Longman, $352 \mathrm{p}$.

Smart, B. (1999). Resisting McDonaldization. London: Sage Publications.

Stillman, T. (2003). McDonald's in question: The limits of the mass market. American Behavioral Scientist, 47(2), 107-118.

Sukapdjo, A. (2013). La restauration rapide: An affront to the collective cultural memory of French cuisine. [Online]. The Coastal Review: An Online Peer-reviewed Journal, 4(1). http:// digitalcommons.georgiasouthern.edu/thecoastalreview.

Suzuki, Y. (1980). Kourigyo no keieigijyutu no iten. Shohi to Ryuutsuu,4(1), 11-16.（鈴木安昭（1980）。「小売業の経営技 術の移転」『消費と流通』4(1), 11-16）(In Japanese)

Toba, T. (2006). Kokkyo wo koeru kourikigyo no "tettai" ni kansuru ichikousatu: Nihonshijyo niokeru oubeikourikigyou no jirei wo tsuujite. Journal of University of Hyogo, 57(4), 287316.（鳥羽達郎 (2006)。「国境を越える小売企業の「撤退」 に関する一考察：日本市場における欧米小売企業の事例を 通じて」『商大論集』57(4), 287-316)（In Japanese）

Toba, T. (2008). Internationalization of retailer and the issue of divestment: an attempt to learn something from negative experiences. The Review of the Osaka University of Commerce, 3(3), 129-147.（鳥羽達郎 (2008)。「小売企業の国際化と撤 退問題一負の経験を通じる学習の試み一」『大阪商業大学論 集』3(3), 129-147） (In Japanese)

Toba, T. (2009). Internationalization of retailing and structure of divestment by cross-border retailer. Ryuutsuu, 24, 103-111. (鳥羽達郎 (2009).「小売業の国際化と撤退の構造」『流通』 24, 103-111) (In Japanese)

Tordjman, A. (1995). European retailing: Convergences, differences and perspectives. In McGoldrick, P, J., \& Davies, G. (eds.), International: Trends and Strategies. Pitman Publishing, 17-50.

Treadgold, A. (1988). Retailing without frontiers. Retail and Distribution Management, 16(6), 8-12.

Treadgold, A. (1991). Dixsons and Laura Ashley: Different routes to international growth. International Journal of Retail and Distribution Management, 19(4), 13-19.

Treadgold, A., \& Davies, R. (1988). The internationalisation of retailing, Oxford Institute of Retail Management. Longman Group, $61 \mathrm{p}$.

Traphagan, J. W., \& Brown, L. K. (2002). Fast food and intergenerational commensality in Japan: New styles and old patterns. Ethnology, 41(2), 34-119.

Tsuruoka, T. (2008). Japanese food service industry: Its business in
China. Journal of Miyagi University School of Food, Agricultural and Environmental Sciences, 2(1), 75-82.（鶴岡公幸（2008）. 「中国に扮ける日系外食チェーンの事業展開」『宮城大学食 産業学部紀要』2(1), 75-82) (In Japanese)

Tsuruoka, T. (2015). Japanese food service industry: Its business in Asia. Global Communication Studies, 2, 161-181.（鶴岡公幸 (2015).「日系外食チェーン企業のアジアに打ける事業展 開」『グローバル・コミュニケーション研究』2,161-181) (In Japanese with English abstract)

Vignali, C. (2001). Mcdonald's: "Think global, act local" - the marketing mix - British Food Journal, 103(2), 97-111.

Wada, M. (1987). Kourigyou no kokusaisenryaku. RIRI Ryuutsuusangyou, 19(4), 11-17. (和田充夫 (1987). 「小売業 の国際戦略」『RIRI 流通産業』19(4), 11-17) (In Japanese)

Williams, D. E. (1992a). Retailer internationalization: An empirical inquiry. European Journal of Marketing, 26(8/9), 8-24.

Williams, D. E. (1992b). Motives for retailer internationalisation: Their impact, structure and implications. Journal of Marketing Management, 8, 269-285.

Williams, D. E. (1994). Motives for international retail expansion: A comparitive analysis. Recent Advances in Retailing and Service Science Conference, Canada (Bunff, Alberta), 7-10.

Wong, M. M. L. (1998). Motives Hong Kong-Japanese international joint ventures in retailing. International Journal of Retail \& Distribution Management, 26(1), 4-12.

Watson, J. L. (1997). Golden arches east: Mcdonald's in East Asia. Stanford Univ. Press.（前川啓治・竹内恵行 - 岡部曜子（訳） (2003).『マクドナルドはグローバルか』新曜社) (In Japanese)

Zhang, B. (2013). Possibility and issues of the Japanese catering enterprises in China: A case study of Yoshinoya, Ajisen and Saizeriya. The Tsuru University Review, 77, 49-66. (張兵 (2013).「日系外食企業の中国進出の可能性と課題 : 吉野 家, 味千ラーメン, サイゼリヤの事例を中心に」『都留文科 大學研究紀要』77, 49-66）(In Japanese)

\section{李 素熙 (いそひ)}

韓国私立大眞大学国際学部卒業

関西学院大学大学院商学研究科 博士課程前期課程修了 現在, 関西学院大学大学院商学研究科 博士課程後期課程 在籍。 